\title{
LOS RECELOS A LA MODERNIZACIÓN AL ESTILO NORTEAMERICANO EN ESPAÑA
}

\author{
DANIEL FERNÁNDEZ DE MIGUEL \\ Universidad Complutense de Madrid \\ danielfernandezdemiguel@yahoo.es
}

(Recepción: 03/11/2014; Revisión: 17/02/2015; Aceptación: 30/05/2015; Publicación: 26/11/2015)

\begin{abstract}
1. ENTRE EL REGENERACIONISMO Y EL AVANCE DE LA SOCIEDAD DE MERCADO.-2. LA MODERNIZACIÓN AL ESTILO NORTEAMERICANO LLEGA A ESPAÑA.-3. LA CRUZADA CULTURAL Y EDUCATIVA CONTRA LA MODERNIZACIÓN COSMOPOLITA EN EL PRIMER FRANQUISMO.-4. LA SOCIEDAD NORTEAMERICANA COMO EPÍTOME DE LOS MALES DE LA VIDA MODERNA.-5. EL CONSERVADURISMO ESPAÑOL SE AVIENE CON LA MODERNIZACIÓN AL ESTILO NORTEAMERICANO.-6. CONCLUSIONES.-7. BIBLIOGRAFÍA
\end{abstract}

\section{RESUMEN}

Durante el primer tercio del siglo xx, los debates en torno a la modernización que se desarrollaron en España situaron a Europa como principal marco de referencia, pero también aparecieron partidarios y detractores de la modernización al estilo norteamericano, en fase claramente ascendente. Tras la victoria franquista en la Guerra Civil, en un momento coincidente con el ascenso de los Estados Unidos a la condición de superpotencia mundial, la modernización al estilo norteamericano despertó más recelos que nunca en sectores importantes de la sociedad española, en ocasiones con la clara connivencia de las autoridades franquistas. La progresiva mejora de las relaciones bilaterales, confirmada por la firma de los Pactos de Madrid en 1953, condujo a que en la segunda mitad de los años cincuenta nuevas élites reformistas dirigieran su mirada hacia el otro lado del Atlántico en busca de referencias económicas e ideológicas de modernización, rompiendo así con la tradición antiamericana dominante hasta entonces en el conservadurismo español.

Palabras clave: modernización, americanización; sociedad de consumo; Imperio del Mercado; intelectuales; tecnócratas; antiamericanismo. 


\title{
THE MISTRUST OF THE AMERICAN MODEL OF MODERNIZATION IN SPAIN
}

\begin{abstract}
Throughout the first third of the twentieth century, the ongoing debates on modernization in Spain took Europe as their main reference point, but there were also partisans and detractors of American-style modernization, which clearly was in the ascendant. Following the Francoist victory in the Civil War, which coincided with the United States' rise to the condition of world superpower, American-style modernization further troubled important sectors of Spanish society, at times with the clear connivance of Francoist officials. The gradual improvement of bilateral relations, confirmed by the signing of the Treaty of Madrid of 1953, lead new reformist elites in the second half of the Fifties to look toward the other side of the Atlantic in search of economic and ideological references to modernization, thus breaking with the anti-American tradition that up to that time was dominant in Spanish conservatism.
\end{abstract}

Key words: modernization; americanization; consumer society; Market Empire; intellectuals; technocrats; anti-Americanism.

\section{$* \quad * \quad *$ \\ 1. ENTRE EL REGENERACIONISMO Y EL AVANCE DE LA SOCIEDAD DE MERCADO}

La llamada crisis de fin de siglo, marcada por la derrota de 1898, vino acompañada en España por la consolidación de una intelligentsia moderna que a lo largo de las tres décadas siguientes desempeñaría un papel central en la vida pública. Entre una gran parte de los intelectuales de la época se convirtió casi en una obsesión encontrar el camino de lo que a principios de siglo se denominó «regeneración» y años más tarde se llamará «modernización» (1). Aunque Europa constituyó el principal marco de referencia desde donde encontrar inspiración para remediar el atraso de España, hubo también otros países que suscitaron interés por su capacidad modernizadora. Ese fue el caso, por ejemplo, de Japón, que había pasado en pocas décadas del estancamiento a la senda del éxito gracias a un enorme esfuerzo industrializador, al establecimiento de la enseñanza generalizada, la regeneración política y la creación de un nuevo ejército, lo que movió a líderes de opinión como Julián Besteiro o Francisco Giner de los Ríos a hacer un llamamiento a la «japonización» de

(1) Véase JuLIÁ (2011). 
España (2). Y también hubo quienes fijaron su mirada en el modelo de sociedad democrática, urbana y tecnológica que representaban los Estados Unidos. En el último tercio del siglo XIX los krausistas e institucionistas habían seguido con atención sus logros educativos y cívicos (3). Y desde principios del siglo XX una pléyade de profesionales diversos, ingenieros y técnicos principalmente, comenzó a viajar al país en busca de nuevas fórmulas para mejorar su rendimiento y eficacia (4).

A partir de 1907, la Junta para la Ampliación de Estudios (JAE), en su intento de formar una élite intelectual, competente científicamente y adaptada a un ambiente cosmopolita, que ejerciera de vanguardia para la modernización social, alentó la colaboración científica y educativa con instituciones y académicos norteamericanos. En los años siguientes surgieron diversas iniciativas que profundizaron en esa línea de colaboración hispano-estadounidense: la Residencia de Señoritas (1915), muy vinculada al International Institute, el Instituto de las Españas de Nueva York (1920), la Fundación del Amo (1929), etc. (5). A pesar de que las actividades de la JAE estuvieron principalmente dirigidas a Europa (6), con el claro predomino de Francia y Alemania, la importancia de esta red de contactos para profundizar en las relaciones académicas y científicas con los norteamericanos no fue desdeñable (7). Significativa de esta buena sintonía fue la visita que, en otoño de 1927, realizó un grupo de académicos españoles asesorados por la Fundación Rockefeller a universidades estadounidenses, en busca de modelos para la Ciudad Universitaria de Madrid. Sus impresiones no pudieron ser más favorables (8).

Así pues, sectores importantes, en términos cualitativos, de la sociedad española, percibieron a los Estados Unidos como un referente atractivo de esa ansiada modernidad que casi todos vinculaban con una Europa idealizada. Estos grupos, sin embargo, fueron minoritarios con respecto al discurso dominante que, como en el resto de Europa, se propagó especialmente en el periodo de entreguerras, y que identificaba a la sociedad norteamericana como una de las más destacadas representantes de la modernidad, pero de un tipo muy diferente a la encarnada por el viejo continente. En este caso, no se resaltaban sus logros científicos, educativos o tecnológicos, o lo avanzado de su cultura democrática y liberal. Lo que se subrayaba eran ciertos aspectos de su funcionamiento eco-

(2) AlmazÁn y Rodao (2006). La mención a Giner de los Ríos en NiÑo (2001): 107.

(3) Véase, por ejemplo, De Labra (1877), De AzCÁRate (1892), Giner de los Ríos (1928) [1898-1901]. También CAPELlán DE Miguel (2011).

(4) Véase GARCíA-Montón (2002). Para profundizar en la fascinación generada por los avances tecnológicos y la modernidad norteamericana en España, véase FERRIS (2010).

(5) Véase SÁnchez Ron (2009).

(6) Y también del Institut d'Estudis Catalans, institución similar creada por las autoridades catalanas en el mismo año 1907.

(7) Véase Delgado (2009): 142.

(8) Chías Navarro (1986): 49-50. 
nómico, social y cultural que, por su carácter pionero, futurista e innovador, llamaban mucho la atención a los observadores europeos, normalmente en un sentido negativo.

En esta visión sobre la modernización al estilo norteamericano los aspectos económicos predominaban sobre el resto. A este respecto, conviene recordar que lo que Cyril Black (9) y, en general, los historiadores económicos, han denominado como «modernización» es casi equivalente al concepto de «industrialización», es decir, hacen referencia a los resultados de un proceso que comenzó en Inglaterra a finales del siglo XVIII, consistente en la aplicación de procesos de producción mecanizados para fabricar bienes a gran escala. Y, al igual que la primera etapa de modernización industrialista llevaba el sello británico, el desarrollo capitalista de finales del siglo XIX y principios del XX, caracterizado por la aparición de nuevas organizaciones empresariales (trusts, holdings, cárteles), nuevas fuentes energéticas (electricidad, petróleo), nuevos métodos de organización del trabajo (fordismo, taylorismo) y nuevos sistemas de financiación, fue percibido como indisociablemente ligado al protagonismo estadounidense. Tanto es así que en la Europa de la primera mitad del siglo xx, la sociedad norteamericana se convirtió en el paradigma de este concepto de modernización. Estados Unidos era sinónimo de eficiencia y tecnología avanzada, de dinamismo industrial y culto al maquinismo, con sus productos «racionalizados» y estandarizados procedentes de las cadenas de montaje, lo que daba lugar al consumo de masas y la mercantilización de la sociedad (10). Se trataba de una fase más de lo que el historiador húngaro Karl Polanyi denominó como «la gran transformación»: el proceso hacia el establecimiento de sociedades de mercado, es decir, de sociedades en las que el mercado impregna la totalidad de la realidad social (11).

La americanización, fenómeno que conforme avanzaban las primeras décadas del siglo Xx, más imparable parecía a ojos de los observadores europeos, consistía en la aplicación sobre Europa de estas innovaciones de índole productiva y económica, con sus correspondientes consecuencias sociales y culturales. Es lo que Victoria de Grazia designa como el avance del Imperio del Mercado estadounidense, es decir, de un capitalismo globalizador orientado al consumidor, que estaba barriendo los valores predominantes del puritanismo, con su énfasis en el ahorro y la austeridad, y que se iba imponiendo sobre la civilización comercial burguesa europea, gracias a su capacidad de adaptar en otros lugares las peculiaridades de su propia sociedad de consumo fundada en el mercado. Las tendencias y actores que contribuyeron a este avance en la primera mitad de siglo fueron muy variados: la propagación del rotarismo por Europa, que contribuyó a difundir entre los hombres de negocios europeos una cultura
(9) BLACK (1966).
(10) Pells (1997): 11.
(11) Polanyi (1944). 
empresarial basada en la ética del servicio; la forja de grandes marcas reconocidas por amplios públicos (Gillette, Ford, Coca-Cola, Kodak, etc.); la creación de nuevas técnicas publicitarias; el imparable éxito de la industria del entretenimiento estadounidense, con su cine a la cabeza... (12). La llegada de esta modernización al estilo norteamericano estuvo acompañada por la introducción de un nuevo lenguaje, el de la eficiencia, la productividad, la optimización, tan íntimamente ligado al fordismo.

Como consecuencia de la expansión del Imperio del Mercado sobre Europa, se asistió a la extensión de prácticas de consumo de origen norteamericano que contenían la promesa o la amenaza, según fuera el punto de vista del observador, de difuminar las distinciones sociales características de la sociedad burguesa europea. Los altos salarios percibidos por los empleados estadounidenses, fundamento de su gran capacidad adquisitiva, iban acompañados de una exaltación publicitaria del hedonismo y el confort, lo que chocaba con los prejuicios clasistas de los estratos más elevados de las sociedades europeas. La sociedad norteamericana era «una civilización de bañeras y frigoríficos» según la descripción del poeta francés Louis Aragon. Tanto los valores del individualismo burgués como los valores católicos, muy extendidos en los países del sur de Europa, se contrapusieron al materialismo y vulgaridad a los que parecía condenar la modernización estadounidense. El temor a la americanización, que ya desde principios de siglo se anunciaba por algunos como imparable (13), se convirtió rápidamente en una de las principales fuentes de antiamericanismo.

Para los críticos con el American Way of Life las ciudades de Nueva York, Chicago y Detroit, convertidas en la avanzadilla de la sociedad de masas, eran las que mejor representaban esta nueva forma de vida que, aun generalizando altas cotas de bienestar material, homogeneizaba a los individuos hacia abajo en términos de civilización, quedando reducidos a la condición de meros autómatas al servicio de la eficiencia económica. La percepción europea de estas grandes ciudades norteamericanas vino acompañada además por la aparición de nuevos prejuicios, como consecuencia de la llegada a los Estados Unidos en el tránsito entre los dos siglos de grandes oleadas migratorias, que condujeron a su sociedad hacia el multiculturalismo (14). Esta falta de uniformidad cultural suscitaba cierta sensación de desarraigo, en un momento, además, en que el darwinismo social gozaba todavía de bastante popularidad. Es sintomático lo que pensaba el escritor Ramón Pérez de Ayala cuando, durante una estancia en Florencia en 1911, conoció allí a unos ciudadanos estadounidenses:

(12) De Grazia (2005).

(13) Véase Stead (1902).

(14) Prejuicios no solo exclusivos de los europeos, en los mismos Estados Unidos se produjo una reacción identitaria, nativista, entre los sectores conservadores de la población WASP frente a la amenaza de la inmigración. Véase, por ejemplo, Higham (1955). 
Confieso que de Norteamérica poseía por aquel entonces muy someras noticias (...) Imaginaba yo los Estados Unidos como país de aluvión, amasado con desgajes, por no decir desperdicios, de muchas razas y muchos pueblos, y a sus naturales como gente andariega, sin el apego tradicional al terruño, al gran hogar patrio, y muy amigos de lozanear por la vieja Europa y de propiciársela en fuerza de aventar puñados de omnipotentes dólares (15).

La creciente influencia económica, política y cultural norteamericana sobre el viejo continente en el periodo de entreguerras fue percibida con angustia por muchos intelectuales europeos, que vivieron la pujanza del modelo estadounidense en términos de dramática inexorabilidad. Coincidiendo con una época en la que los intelectuales gozaron de un destacado protagonismo social, se desarrolló un antiamericanismo de carácter elitista, encuadrado dentro de los temores al avance de un modo de vida que parecía ineluctable, un «futuro» al que nadie podría escapar (16). Y en el que los intelectuales, huelga decirlo, quedarían previsiblemente relegados a una posición marginal. Se consideraba que la mercantilización creciente de la sociedad, ejemplificada por la mecanización y la aplicación de los métodos de producción fordista y taylorista a todos los ámbitos de la vida, conduciría a la estandarización de la humanidad. Aunque estas voces críticas surgieron desde todo el espectro ideológico, fueron los intelectuales conservadores los que más se destacaron en alertar sobre el futuro distópico que llegaría con el triunfo de la modernización al estilo norteamericano. En general, observaban el momento como el tránsito desde un viejo orden, idealizado, en el que el hombre era centro y dueño de su destino, hacia uno nuevo en el que sería un engranaje más del mercado, pieza pasiva del maquinismo y la tecnología.

No es casualidad que floreciera en estos años en gran parte de Europa, especialmente en Francia, la nación que todavía reivindicaba el cetro de la alta cultura, una fuerte corriente antiamericana, que se tradujo en la publicación de multitud de obras que alertaban sobre los defectos de la sociedad estadounidense (17). La modernización al estilo norteamericano, al igual que la revolución soviética, significaba el triunfo del hombre estandarizado, de un hombre nuevo

(15) Ramón Pérez de Ayala, «El país del futuro», El Imparcial, Madrid, 30 de julio de 1913.

(16) La lista de intelectuales europeos que expresaron su desdén a los Estados Unidos en esta época es interminable: Martin Heidegger, Ernst Jünger, Gerhart Hauptmann, Moeller van den Bruck, D.H. Lawrence, Louis Aragon, Paul Morand, Charles Maurras, el conde Keyserling, José Ortega y Gasset, etc.

(17) J.-L. CHASTANET, L'Oncle Shylock ou l'imperialisme américain à la conquête du monde (1927); ANDrÉ SiEgFrIED, Les États-Unis d'aujourd'hui (1927); RÉGIS MichaUd, Ce qu'il faut connaître de l'ame Américaine (1929); GEORGE DUHAMEL, Scènes de la vie future (1930), KADMICoHen, L'abomination américaine (1930); Robert ARon y ARNAud Dandieu, Le Cancer Américain (1931). En Alemania, por contra, los logros tecnológicos y económicos estadounidenses suscitaron gran interés, con más de cincuenta obras publicadas en los años veinte sobre el país, sin ese carácter tan hostil, en general, que tuvo la literatura francesa hacia la vida norteamericana. Véase Nolan (1994). 
que ponía su vida al servicio de la técnica. Sorprendentemente, los sectores culturales conservadores iban incluso más allá y había quienes tendían a considerar la americanización como un peligro aún mayor que el comunismo (18). Las consecuencias deshumanizadoras de este tipo de modernización saltaban a la vista, reduciendo la sociedad a la categoría de un hormiguero, una metáfora ampliamente divulgada en la época:

En los Estados Unidos, ese país al otro lado del Atlántico que nos llama la atención por contener las promesas del futuro, lo que golpea al viajero occidental es el encaminamiento de los comportamientos humanos hacia lo que entendemos como comportamientos de insectos: misma eliminación del individuo, misma disminución y unificación progresiva de los tipos sociales, misma ordenación del grupo en castas especializadas, misma sumisión de todos a las exigencias oscuras de eso que Maeterlinck denomina el genio de la colmena o de la termitera (19).

Este tipo de críticas a la vida norteamericana alcanzaron tras la Primera Guerra Mundial un eco considerable. Constituían la respuesta a la atracción que, sobre un número creciente de europeos, ejercía la modernización al estilo norteamericano, con su sugerente cultura del consumo. En reacción a este éxito, determinados ambientes intelectuales, políticos y religiosos del viejo continente empezaron a defender su «estilo de vida» de modo cada vez más reaccionario y defensivo.

\section{LA MODERNIZACIÓN AL ESTILO NORTEAMERICANO LLEGA A ESPAÑA}

La sociedad española del primer tercio del siglo Xx, en especial durante el periodo de entreguerras, fue receptiva a este tipo de modernización en sus principales ciudades. Proceso que no se puede entender sin el acusado crecimiento económico que, con algunas oscilaciones, se dio a lo largo de esta época, muy particularmente en los años comprendidos entre 1914 y 1930, que fueron además de un gran dinamismo en el sector constructor e inmobiliario (20). Fue un periodo de crecimiento de las ciudades, de avance de la industrialización en algunos puntos del país, que fueron acompañados de cambios significativos en los hábitos sociales, las costumbres y las relaciones sociales de una parte de la población (21). En ciudades como Barcelona o Madrid se dieron en el periodo de entreguerras los primeros pasos en la transición, llena de contradicciones, vaivenes y resistencias, de una cultura autóctona y popular a otra más cosmopolita. La influencia de la industria cultural de consumo norteamericana fue determinante en este proceso. La puesta en circulación de mercancías culturales

(18) GULdDAL (2011): 94.

(19) Duhamel (1930): 224. Traducción del autor.

(20) CARRERAS Y TAFUNELL (2006): 455-499.

(21) Aguado y Ramos (2002): 95. 
de procedencia estadounidense, aun sin lograr en España el amplio alcance social de su país de origen, sí propició la aparición de una cultura diferente, dotada a menudo de una cierta impronta mesocrática (22).

En los años veinte, aparte de consolidarse en la sociedad española el uso de ciertos productos representativos de la vida moderna, como el automóvil o la radio (23), se produjo también una revolución silenciosa en los hábitos de consumo y ocio de las clases medias y altas de los entornos urbanos, en una dirección más cosmopolita. Llegaron los bares y restaurantes modernos, como el Maxim's en 1919, el primer bar americano establecido en Madrid, en la calle de Alcalá. Florecieron los grandes almacenes y las tiendas de diseño. El cine, gran invento moderno y barato, comenzó a reemplazar al teatro como espectáculo preferido del público. Y los bailes importados del otro lado del Atlántico, como el fox-trot o el charlestón, tuvieron una excelente acogida en los ambientes más esnobs. La confluencia de estas nuevas formas de ocio y esparcimiento «a la americana» contribuyeron a la creación de un nuevo imaginario en amplias capas de urbanitas. Un nuevo mundo basado en el consumo y la publicidad se abría paso frente a los espectáculos habituales, como los toros, el teatro o el género chico, y las fiestas tradicionales castizas o religiosas (24), provocando la incomprensión y disconformidad de aquellos que se resistían a la extinción de una cultura basada en pautas más tradicionales y locales. Sintomático del resquemor que produjeron en estos círculos sociales e intelectuales las muestras cada vez más visibles del avance del Imperio de Mercado en la sociedad madrileña, son las palabras del pintor José Gutiérrez Solana sobre la Gran Vía en un artículo de 1923 publicado en su obra Madrid callejero:

Grandes escaparates, con pianolas, gramófonos, música mecánica, alternando con fotografías y autógrafos de divos más o menos melenudos; fondas, pensiones, manicuras y círculos y cafés exhibicionistas y, sobre todo, los restaurantes, muy frecuentados por las tardes y en los que se baila con música de negro.

Hay también bares americanos, en que es necesario encaramarse como un mono sentado en un alto taburete para llegar al mostrador; han tenido poca aceptación; pero no deja de verse en ellos siempre algún idiota vestido de smoking fumando una pipa (25).

Este proceso de modernización no fue bien recibido por los sectores más conservadores, comenzando por la Iglesia, que emprendió en estos años una campaña de «remoralización» de la sociedad (26). La preocupación suscitada por el empuje de una cultura ligada al movimiento obrero así como por el éxito de películas y modas estadounidenses y de otras partes de Europa, llevó a la

(22) BAKer y CAStro (2008): 18.

(23) Artículos, por supuesto, de lujo, accesibles solo para una parte ínfima de la población.

(24) Véase NiÑo (2012): 195-196.

(25) Citado en BAKER (2009): 39.

(26) Aguado y Ramos (2002): 127. 
creación de numerosas organizaciones para contrarrestar el avance de esta modernización de las costumbres (27). Entre ellas, la más destacada fue Acción Católica, en estrecha vinculación con la jerarquía eclesiástica. Uno de sus principales propósitos era lograr la recristianización de las costumbres y de la vida pública, en una sociedad amenazada por la apertura a influencias del extranjero.

En los años veinte, la conquista de las salas españolas, como las del resto de Europa, por parte de la cinematografía norteamericana, encrespó a los sectores culturales más inmovilistas del país. Los nuevos hábitos de consumo cultural chocaban con las rígidas barreras sociales de distinción existentes en sociedades como la española de entonces (28). Los principales damnificados por el éxito de las películas de Hollywood fueron el teatro y el género chico. El cine norteamericano aceleró en los años veinte la crisis de estos espectáculos más tradicionales, lo que llevó al final de la década, por ejemplo, al cierre de uno de los teatros más emblemáticos del Madrid de la Restauración, el Teatro Apolo, situado en la calle de Alcalá. Este declive de las artes escénicas fue vivido con inquietud por quienes se sentían fieles a pautas de vida más tradicionales y selectas. Su actitud solía ser la de un desdén altivo, con cierto punto de nostalgia romántica, frente a los seguidores de las nuevas tendencias de ocio: «Los que condenan a muerte al teatro, favoreciendo otros espectáculos, no sienten en su espíritu los destellos del pensamiento y las vibraciones de la poesía. Son seres de una vulgaridad lamentable» (29). En estas críticas también era corriente encontrar el sello de un anticapitalismo moralizante, influido por la doctrina social de la Iglesia. Por ejemplo, en julio de 1929, quien se convertiría años después en uno de los críticos cinematográficos más reconocidos en los medios conservadores, Carlos Fernández Cuenca, avisaba de la «tremenda amenaza» que suponía el cine como herramienta propagandística del capitalismo norteamericano en Europa. Gracias al cine, cada día, miles de pantallas reproducían la vida y costumbres yanquis por el viejo continente, presentando a la tierra del dólar como la «meca ideal de los tiempos modernos» y haciendo además con ello un provechoso negocio para sus «businessmen» (30).

La música y los bailes procedentes de los Estados Unidos, como el jazz y el fox-trot, sufrieron también las iras de los grupos más tradicionalistas de la sociedad, que los consideraban representativos de la degeneración moral y el nihilismo característicos de la modernidad norteamericana. Como señalaba el periodista Juan Spottorno y Topete en la revista Blanco y Negro, «el fox-trot es

(27) Por ejemplo, las Ligas contra la Pública Inmoralidad, la Legión Católica Española, las asociaciones católicas de padres de familia, etc.

(28) De Grazia (2005): 140.

(29) Fortunio, «El público de los teatros, cinemas y 'music-halls'», La Época, Madrid, 30 de julio de 1927, n. ${ }^{\circ} 27.323: 1$.

(30) Carlos Fernández Cuenca, «Cinematografía», La Época, Madrid, 29 de julio de 1929: 3. 
el baile de los indiferentes, de los que se encogen de hombros ante la vida» (31). La cantante y bailarina estadounidense Joséphine Baker, afincada en París desde 1925, se convirtió en la diana perfecta de estos ataques por su carácter icónico. Así, cuando visitó Madrid en 1930, desde la revista Crónica se aprovechaba para contraponer su primitivismo e irreverencia con la armonía y sutileza de la bailarina rusa más famosa de la época, Anna Pavlova:

De la calle Jovellanos - dieciochesca- a la Avenida del Metropolitano, entre los rascacielos neoyorquizantes de Cuatro Caminos. Ayer, Anna Pavlova, quintaesencia imperial de una cultura europea que tal vez periclita; la punta de sus pies, en la danza clásica, es como el ápice de una civilización blanca. Hoy, Josefina Baker, su antípoda, brote pujante y vencedor de un arte negro que se adueña -a cuatro piesdel mundo. ;Venturoso azar de empresarios que en una misma semana someten la sensibilidad madrileña a la prueba de dos concepciones antagónicas del ritmo humano! Frente al sentido jerárquico de la cúpula, el sentido democrático de la llanura; contra la gravedad del arte puro, del arte por el arte, la corrosiva burla del arte por el capricho, instintivo, epatante... (...) Josefina Baker es... el humorismo, cifra del nuevo caos, cocktail que resiste al análisis de los confusos deseos actuales del mundo; ¿retorno a lo antiguo, vuelta a lo primitivo, al plátano paradisíaco y el kanguro, o ansia bolchevique de una supercivilización subversiva de todos los valores aceptados? (32).

Lo curioso es que, como la propia Joséphine Baker, gran parte de las importaciones en España de estos nuevos productos y tendencias, como el jazz o los bares americanos, no procedían directamente de los Estados Unidos, sino que eran muestras de un cosmopolitismo traído de Norteamérica a través de París (33).

Aunque los círculos conservadores de la sociedad fueron los que con más empeño expresaron su malestar ante el avance de la modernización al estilo norteamericano, no fueron los únicos que se sintieron incómodos (34). Para algunos líderes de opinión e intelectuales de talante menos conservador, la creciente popularidad del American Way of Life se vivió también con preocupación. Fue el caso, por ejemplo, del escritor y político socialista Luis Araquistáin, que a comienzos de los años veinte advertía sobre las negativas consecuencias que para la libertad individual entrañaba la civilización norteamericana, y recurría como tantos otros intelectuales de la época a la metáfora del hormiguero para representar el tipo de vida que se daba en los Estados Unidos (35). O del

(31) J. Spottorno y Topete, «Al oído de una colegiala», Blanco y Negro, Madrid, 29 de febrero de 1920: 6 .

(32) G.O., «Josefina Baker, la mulata friolenta que viene a beber un poco de sol de España», Crónica, Madrid, Año II, n. ${ }^{\circ}$ 13, 9 de febrero de 1930: 4.

(33) BAKER (2009): 63.

(34) Véase NiÑo (2009).

(35) ARaquistain (1924): 41. Curiosamente, en los años cincuenta, Luis Araquistain se convirtió en una de las pocas voces pro-americanas del socialismo español. 
republicano Marcelino Domingo, que acusaba a los yanquis de someter a Cuba y al resto de América Latina mediante su capitalismo despiadado, alertando de lo que le podría ocurrir también a España en un futuro próximo (36). Y cabe destacar, asimismo, el papel de Ortega y Gasset y su Revista de Occidente, que a finales de los años veinte publicó varios artículos de pensadores alemanes muy críticos con la modernización al estilo norteamericano, desde una perspectiva marcadamente eurocentrista (37). En sus propios escritos de esta época, el filósofo madrileño dejó constancia de sus reticencias al modelo estadounidense (38).

Tras la Guerra Civil, las críticas al American Way of Life encontraron un terreno aún más fértil para prosperar, en sintonía con la ideología de los vencedores de la contienda. En la España del primer franquismo, la identificación entre los Estados Unidos y la vida moderna se inscribía en una larga tradición antiamericana de los sectores más conservadores del país (39), lo que exacerbó la hostilidad hacia todo lo que representaba la modernización de origen estadounidense.

\section{LA CRUZADA CULTURAL Y EDUCATIVA CONTRA LA MODERNIZACIÓN COSMOPOLITA EN EL PRIMER FRANQUISMO}

Tras la victoria franquista en la Guerra Civil, el proceso de modernización que había experimentando España en los años de entreguerras quedó abruptamente interrumpido. La enorme contracción económica que sufrió el país como consecuencia de la guerra vino acompañada por las políticas autárquicas de las nuevas autoridades, tanto en el ámbito económico como en el cultural. Edward Baker es muy gráfico al describir lo que significó la dictadura franquista en uno de los símbolos de la modernidad en el periodo anterior a la guerra, la Gran Vía madrileña: «La Gran Vía de entreguerras poco menos que desapareció, y su reemplazo, pese a las similitudes de superficie, guardaba con ella la misma distancia que un Madrid abierto a las corrientes culturales del planeta entero con otro aterrorizado, provincianizado y cerrado sobre sí mismo» (40).

Una de las consecuencias del establecimiento del régimen franquista fue la puesta en marcha de una verdadera contrarreforma cultural y educativa frente a las corrientes aperturistas y cosmopolitas que habían caracterizado los años pre-

(36) Domingo (1923): 233-234.

(37) Artículos de Mortiz Geiger, Paul Fechter, Teodore Lucddecke, el conde Keyserling, etc.

(38) Las opiniones de Ortega sobre Estados Unidos pueden encontrarse en La rebelión de las masas (1930), sobre todo en su Prólogo para franceses (1937), así como en una serie de artículos de 1932 recogidos bajo el título Sobre los Estados Unidos y en un ciclo de conferencias pronunciadas en Buenos Aires en 1928.

(39) Véase FernándeZ de Miguel (2011).

(40) BAKER (2009): 12. 
cedentes. El patriotismo de carácter católico y conservador que, durante la Guerra Civil, se había convertido en una de las señas de identidad del bando nacional, continuó siendo promovido por las autoridades en los primeros años del franquismo. En un contexto de simpatía hacia los países del Eje y, tras la derrota de estos, de aislamiento internacional, este nacionalismo fue terreno abonado para la propagación de la xenofobia y, en particular, del antiamericanismo.

En el ámbito educativo, un terreno siempre muy sensible para los sectores conservadores y donde desde un primer momento se concedió a los católicos la dirección de la nueva política, hubo un rechazo absoluto de las «doctrinas pedagógicas del extranjero», porque eran, según decía el BOE, «hipócritas, extrañas, exóticas y despóticas» (41). Para las nuevas autoridades educativas, la función primordial de la educación no era la formación de un capital humano cualificado, sino el control ideológico y la transmisión de valores. En el preámbulo de la primera gran ley promulgada en el ámbito educativo, la Ley de la Reforma de la Enseñanza Media, se señalaba como uno de los principales objetivos a perseguir la «revalorización de lo español, la definitiva extirpación del pesimismo antihispánico y extranjerizante, hijo de la apostasía y de la odiosa y mendaz leyenda negra» y se encontraba en el «mimetismo extranjerizante» un síntoma bien patente de decadencia (42).

En esta tarea, los sectores eclesiásticos desempeñaron un papel fundamental. Gran parte del clero, inmerso en el clima de cruzada creado en el bando franquista durante la Guerra Civil, se encontraba en la posguerra muy radicalizado. Los católicos de la línea posibilista, procedentes del catolicismo social de principios de siglo, habían quedado relegados a posiciones marginales. En un ambiente social y cultural caracterizado por el nacionalcatolicismo (43), a pesar de los fútiles intentos por parte de algunos falangistas de conducir el Estado hacia una línea más puramente fascista (44), los eclesiásticos españoles afines al tradicionalismo pudieron exponer sin cortapisas sus diagnósticos y remedios sobre la situación de España, que eran diametralmente opuestos a los que habían propuesto las décadas precedentes los miembros más activos y reformistas de la intelligentsia española, partidarios de la modernización del país. En la interpretación nacional-católica España aparecía acosada por la modernidad, una modernidad de origen foráneo, que había apartado al país de sus raíces católi-

(41) SOPEÑA (1994): 17.

(42) Boletín Oficial del Estado, 23 de septiembre de 1938.

(43) Véase BotTI (2008): 149-194; Álvarez JunCo (2001): 433-464; ÁlvarEz Bolado (1976).

(44) Esfuerzos que ya habían quedado muy debilitados cuando Franco impuso por decreto la unión de falangistas y tradicionalistas en un solo partido, FET de las JONS, en abril de 1937. Aunque los fulgurantes éxitos de los alemanes en las primeras etapas de la Segunda Guerra Mundial reavivaron la posibilidad de establecer un régimen fascista en España, con la progresiva agonía de la Alemania nazi a partir de 1942 los sueños de crear un Estado realmente fascista mantenidos por algunos falangistas, con Serrano Suñer a la cabeza, quedarían definitivamente postergados. 
cas, poniendo en peligro su propia supervivencia como nación. Por ejemplo, el obispo de Tenerife, Albino G. Menéndez-Reigada, autor de un Catecismo patriótico español muy utilizado en las escuelas, localizaba el origen de todos los males de España en «haberse olvidado de sí misma y querer vivir de prestado, copiando al extranjero» (45). Menéndez-Reigada presentaba un país sitiado en su lucha contra «los siete pecados capitales del mundo moderno»: el marxismo, el liberalismo, la democracia, el judaísmo, el capitalismo, la masonería y el separatismo, todos ellos agrupados bajo la forma de una conspiración internacional (46). El liberalismo era, en opinión del obispo, el mal mayor, «el padre» de todos los demás.

Teodoro Rodríguez, agustino del monasterio de El Escorial, publicista muy popular en la España de la posguerra, propagó también la idea de que la Guerra Civil y la decadencia nacional fueron producto del cosmopolitismo moderno, de la apertura del país a los influjos de fuera. Según su opinión, las «modas y costumbres indecentes» procedentes del extranjero habían corroído la vida española (47). Refiriéndose a los intercambios educativos con el extranjero auspiciados por la JAE en los años veinte y treinta, Teodoro Rodríguez encontraba en ellos una de las causas de la tragedia española:

Confiadamente esperamos que no se repetirá la incomprensible locura de gastar España una millonada en enviar jóvenes a estudiar en el extranjero, con lo cual solo se conseguía, salvo en contadas excepciones, como era natural, extranjerizarlos y que volviesen a la patria menospreciándola y con hábitos, aficiones e ideas de borroso e insípido cosmopolitismo (48).

Otro religioso, en este caso el jesuita Feliciano Cereceda, profesor del Colegio de San José de Valladolid, publicó en 1940 un libro de texto para alumnos de bachillerato en el que se transmitía también una interpretación xenófoba y reaccionaria sobre el origen de los males del país. En opinión de Cereceda, el proceso de emancipación de las colonias americanas de España en el primer tercio del siglo XIX había respondido a «la consigna que desde hace cuatro siglos impera en la política universal: «Que España no sea grande» (49). Cereceda ofrecía, «frente a un mundo sumido en lo material, en el maquinismo, en el progreso ciego», la imagen de una España idílica, anticipo de esa «reserva espiritual de Occidente» que pocos años después tanto se emplearía por la propaganda franquista. Una España, en definitiva, que resistía con firmeza, junto a la única compañía de las naciones hispanoamericanas, al desmoronamiento del resto del mundo a causa de una destructiva modernidad (50).

(45) GonZÁLEZ MENÉndEZ-REIGADA (1939a): 34.

(46) GonZÁLEZ MENÉNDEZ-REIGAdA (1939b): 16.

(47) RoDRíGUEZ (1940): 11-12.

(48) Ibíd., 15.

(49) CERECEDA (1940): 255.

(50) Ibíd., 267-268. 
Entre las naciones donde, a ojos de los franquistas, la modernidad y sus aciagos valores estaban más arraigados, sobresalían los Estados Unidos. Su condición de avanzadilla de la modernidad se agravaba además por su creciente poderío y capacidad de influencia en el exterior. Por ello, Iniesta Corredor, inspector de Primera Enseñanza, consejero nacional de Educación y asesor técnico de la Dirección General de Primera Enseñanza, ensalzaba en 1941, en una obra que daba consignas a los maestros sobre la educación en la España franquista, la reforma educativa llevada a cabo en la República Dominicana por el general Trujillo,

[...] porque vemos en ella el esfuerzo meritísimo de un pueblo que ansía llegar a la creación de un sistema propio, libre del pasado agnosticismo que aún persiste en ciertos sectores del mundo y -solamente esto da gran realce hispánico- libre también de la garra del dólar, que en estos instantes, con el falso pretexto de una seguridad americana, pretende sojuzgar los países hispanos (51).

Iniesta Corredor avisaba que los hispanoamericanos no eran los únicos sometidos a la amenaza yanqui, también los europeos estaban coaccionados por «la democracia imperialista y plutócrata yanqui».

Frente a los valores asociados a la modernidad al estilo norteamericano, en la España del primer franquismo se estiló una retórica quijotesca, que trató de presentar la singularidad del país como un ejercicio de voluntad por mantenerse al margen de esa modernidad corruptora e invasiva. Los valores hispanos, tal y como había expuesto Manuel García Morente en su Idea de la Hispanidad (1941), eran los de un mundo pre-moderno, contrarreformista, caballeresco, basado en los ideales del honor y el heroísmo ora del hidalgo español, ora del caballero cristiano:

La imagen intuitiva que mejor simboliza la esencia de la hispanidad es la figura del caballero cristiano: caballerosidad y cristiandad en fusión perfecta e identificación radical, concretadas en una personalidad absolutamente individual y señera. Y ese caballero cristiano español ha sido paladín, grande contra la mezquindad, arrojado contra la timidez, altivo contra el servilismo, más palpitación que cálculo, con culto del honor, con idea de la muerte, religioso e impaciente de eternidad (52).

En los libros de lectura para niños se remarcaba la excepcionalidad de España, su lucha quijotesca contra la uniformidad y el hedonismo extendidos por el resto del mundo. Se transmitían ideas, en definitiva, que abundaban en la línea de un nacionalismo autosuficiente, ajeno al mundo moderno: «Queremos una España dueña de sus destinos, árbitro de sus propias empresas, que se baste a sí misma, es decir, que no esté esclavizada a los Estados capitalistas judaicos» (53). Como se decía en un libro de lectura para niños del que se hi-

\footnotetext{
(51) INIESTA CORREDOR (1941): 111.

(52) Del Arco y Garay (1942): 272.

(53) SÍMBOLOS DE ESPAÑA (1939): 26.
} 
cieron más de veinte ediciones, el quijotismo típicamente español era moralmente superior al prosaico afán de lucro que caracterizaba a otras naciones: «Don Quijote era como España: no quería dineros, quería honra. Y no le temía a nada ni a nadie por defender la justicia y la verdad» (54). Había muchos miembros del régimen franquista que creían de veras en este discurso y querían transmitirlo a las nuevas generaciones. Fue un periodo de explícita y militante antimodernidad. Y, por otro lado, ese espíritu quijotesco que despreciaba el progreso material y las comodidades de que gozaban sociedades como la norteamericana, se adaptaba perfectamente a la situación de pobreza y subdesarrollo del país. Se intentaba presentar el atraso material español, su pobreza, su incapacidad de modernizarse, como consecuencias de la especial idiosincrasia española. Menéndez-Reigada expresaba muy bien esta singularidad nacional, apelando a un patriotismo romántico:

Se ha dicho muchas veces, que el español es sanguinario por temperamento y despreciador de la vida y de la muerte; indiferente al dolor, tanto propio como ajeno; y aventurero y buscador de empresas, en las que se pueda conquistar, más que dinero, gloria. Y hay en todo esto mucho de verdad. Encaja mal con nuestro carácter esa concepción rastrera de la vida, que pone su ideal en la comodidad y el confort (55).

Esa concepción tan prosaica y vulgar de la vida había alcanzado en la sociedad norteamericana el terreno más propicio para desarrollarse y expandirse hacia otras latitudes. Las noticias e imágenes que llegaban a la España del primer franquismo sobre la modernización al estilo norteamericano se percibían a través del filtro de un amplio conjunto de estereotipos heredados (56). Este conjunto de predisposiciones hacia Estados Unidos está muy relacionado con lo que Arno J. Mayer definió de manera esclarecedora como «persistencia del Antiguo Régimen» en Europa (57), es decir, la persistencia hasta bien entrado el siglo XX de esquemas mentales preindustriales, preburgueses y predemocráticos en una gran parte de las poblaciones europeas de la época, a quienes resultaba difícil de comprender y aceptar numerosos aspectos de la vida norteamericana, desde el rol de sus mujeres hasta el papel de la tecnología en su vida cotidiana.

\section{LA SOCIEDAD NORTEAMERICANA COMO EPÍTOME DE LOS MALES DE LA VIDA MODERNA}

En el caso español, además, la percepción de la modernidad estadounidense estaba muy condicionada por la mirada hispanoamericana. En América Latina,

(54) SERRANO DE HARO (1943): 75.

(55) GonZÁleZ MenÉNDEZ-Reigada (1939b): 17-18.

(56) RodrígueZ JimÉnEZ y FERNÁNDEZ DE Miguel (2011).

(57) MAYER (1981). 
coincidiendo con la derrota española frente a Estados Unidos en la Guerra de 1898 , se generó una corriente intelectual de amplio alcance muy crítica hacia el avance de la modernización al estilo norteamericano, que fue precursora de la que luego se extendería en Europa tras la Primera Guerra Mundial. Se temía que, gracias a su creciente fortaleza política, económica e internacional, el modelo de civilización estadounidense acabara por subsumir a los pueblos hispanoamericanos. Como ocurría desde mediados del siglo XIX, la débil «raza latina» se sentía en peligro frente al vigor de la «raza anglosajona», por utilizar el lenguaje de la época. Rubén Darío, que entre 1898 y 1906 se mostró muy activo en defensa de la hispanidad frente a los Estados Unidos, sintetizaba perfectamente el malestar que generaba en estos círculos la amenaza del American Way of Life mediante el empleo de una retórica que, como es habitual cuando se enfrentan sociedades tan desiguales en su grado de desarrollo económico, destacaba la pureza y elevada espiritualidad de una hispanidad idealizada frente a la barbarie tecnológica y materialista de la civilización anglosajona:

Y los he visto a esos yankees, en sus abrumadoras ciudades de hierro y piedra y las horas que entre ellos he vivido las he pasado con una vaga angustia. Parecíame sentir la opresión de una montaña, sentía respirar en un país de cíclopes, comedores de carne cruda, herreros bestiales, habitadores de casas de mastodontes. Colorados, pesados, groseros, van por sus calles empujándose y rozándose animalmente, a la caza del dollar. El ideal de esos calibanes está circunscrito a la bolsa y a la fábrica. Comen, comen, calculan, beben whisky y hacen millones. Cantan ¡Home, sweet home! y su hogar es una cuenta corriente, un banjo, un negro y una pipa. Enemigos de toda idealidad, son en su progreso apoplético, perpetuos espejos de aumento (58).

La publicación en 1900 de Ariel, del escritor uruguayo José Enrique Rodó, obra muy bien acogida en España, obedecía a la necesidad de contrarrestar el soft power emanado de la nación de Washington, que se traducía en la seducción creciente que generaban los éxitos de la sociedad estadounidense entre los jóvenes latinoamericanos. Se corría el riesgo de que la "nordomanía" que afectaba a estos jóvenes facilitara la aparición de una «América deslatinizada por propia voluntad, regenerada luego a imagen y semejanza del arquetipo del Norte» (59). Ariel marcó la pauta de la argumentación contra el utilitarismo, el materialismo y el «falso igualitarismo que aspira a la nivelación de todos por la común vulgaridad», identificados con la modernización estadounidense. Numerosos intelectuales y activistas latinoamericanos seguirían su ejemplo en los años siguientes, como el venezolano Rufino Blanco-Fombona (60), el colombiano José María Vargas Vila (61) o el argentino Manuel Ugarte (62), cuya

(58) DARÍO (1898).

(59) Rodó (1947) [1900]: 88.

(60) BlanCo-Fombona (1902).

(61) VARgas Vila (1930). La primera publicación de la obra tuvo lugar en 1903, en la revista Némesis de Nueva York.

(62) Ugarte (1920). 
influencia se dejó sentir principalmente en los países latinos de Europa, sobre todo en España.

En el primer franquismo, este tipo de discurso que aunaba antiamericanismo y rechazo a todo lo que significara modernización, estuvo muy extendido. Las condiciones para ello eran propicias. Nos encontramos con un país que estaba alcanzando tardíamente el tren de la modernidad, con un régimen político afín a los países del Eje y, tras la derrota de estos, aislado internacionalmente, con una intelectualidad proclive a Hispanoamérica, y donde ocupaban el poder sectores sociales muy militantes frente a cualquier atisbo de modernización, cuya identidad nacional estaba ligada precisamente a un catolicismo de carácter reaccionario. De ahí que durante los primeros años del franquismo, los grupos conservadores que monopolizaron el poder político y social del régimen, propagaran una opinión muy negativa de la modernización al estilo norteamericano. En medios falangistas, católicos y militares abundaron retratos caricaturescos de la vida estadounidense, que se nutrían tanto del acervo de imágenes antiamericanas que se habían ido creando en España desde el siglo XIX, como de los tópicos y exageraciones difundidos por Europa y América Latina en las primeras décadas del Xx. La sociedad estadounidense se convirtió en el símbolo de todos los males de la vida moderna y, en consecuencia, hubo un intento por parte de estos grupos de mantener a los españoles a salvo de su perniciosa influencia. Tarea nada fácil, dada la fruición con que gran parte de la sociedad recibía las películas de Hollywood y otras manifestaciones paradigmáticas de la creciente influencia cultural estadounidense por el mundo, como el jazz.

Precisamente el cine, «lo que más influencia ejerce en la vida moderna» según sostenía Manuel Bendala en el diario $A B C$ (63), constituía, a ojos de los franquistas, la vía de entrada en la península de modas y hábitos extraños, incompatibles con el tradicional modo de vida español. Esta contaminación se efectuaba especialmente, como denunciaban las publicaciones falangistas y católicas de la época, a través de los jóvenes y las mujeres, los dos grupos considerados más inermes frente a la capacidad de manipulación del cine de Hollywood. La popularidad de las películas norteamericanas en la España de la posguerra fue directamente proporcional a la virulencia que en su contra emplearon los medios falangistas y católicos más radicales, cuyos llamamientos a las autoridades para que llevaran a cabo una política más activa en contra de la hegemonía del cine estadounidense, chocaron siempre con el escaso margen de maniobra de estas (64). El jazz, aunque no constituía un entretenimiento tan masivo como el cine, contaba con un número creciente de seguidores en la España de los años cuarenta. Al igual que sucedía con el séptimo arte, se daba la

(63) Manuel Bendala, «La moda cinematográfica», $A B C$, Sevilla, 15 de diciembre de 1944: 15

(64) Véase León Aguinaga (2010). 
coexistencia de un discurso radical en su contra, con la tolerancia de las autoridades, al menos limitada, a su práctica (65).

En estos años fue habitual que los miembros más militantes del régimen achacaran a la influencia estadounidense las novedades modernizadoras que se producían en el estilo de vida patrio. Por ejemplo, el periodista y propagandista franquista Joaquín Arrarás, se lamentaba de la falta de sosiego y silencio que se había apoderado de las ciudades y pueblos españoles, como consecuencia de la importación del frenético ritmo de vida característico de la sociedad estadounidense. Para dar mayor robustez a su postura antiamericana, Arrarás aludía al «aumento espantoso» de enfermos mentales en los Estados Unidos como producto de un estilo de vida sometido a «los ruidos, la prisa, la multiplicidad de emociones, la radio (...), el cine (...), los cock-tails, el motor...» (66). La identificación entre modernización y americanización convertía a los Estados Unidos en el chivo expiatorio de las angustias y tensiones generadas por el desarrollo capitalista en países más atrasados económicamente, como la España de entonces, haciendo parecer como exógenos el origen de estos problemas (67).

Mientras numerosos católicos, falangistas y militares se atribuían la representación de valores ancestrales, y pretendían verse a sí mismos como el último reducto de la civilización occidental, que ellos identificaban con el catolicismo contrarreformista, la sociedad norteamericana encarnaba lo contrario, el prosaísmo de la racionalidad funcional del cálculo y de la eficacia. Mientras España producía Don Quijotes y caballeros cristianos, austeros materialmente pero repletos de altos valores, el American Way of Life ofrecía el ambiente más propicio para que proliferaran hombres avariciosos y simples solo preocupados en ganar dinero, como su cine se encargaba de recordar:

Por cada personaje empeñado en el estudio, por cada Pasteur o cada Edison cuya vida se ha llevado recientemente al celuloide-, las películas norteamericanas nos presentan centenares y millares de hombres de presa, cuya única ilusión y razón de ser consiste en acumular millones en el mundo cruel de la alta especulación o en el de la baja urdimbre negociante (68).

Los viajeros españoles a Norteamérica durante los años cuarenta contribuyeron también por lo general a difundir la imagen de una modernización destructora, donde todo se permitía, dada la ausencia de límites en una nación joven y sin historia. Por ejemplo, el periodista Gaspar Tato (69) y el escritor Joaquín Calvo Sotelo coincidían tras visitar los Estados Unidos en lamentar la ausencia de Edad Media en la historia del país, un periodo muy idealizado por los con-

(65) IGLESIAS (2010): 127.

(66) Joaquín Arrarás, «El miedo al silencio», $A B C$, Madrid, 11 de agosto de 1944: 6.

(67) KLAUTKE (2011): 1126.

(68) CARlos Fernández Cuenca, «Las tres caras del cine yanqui», Haz, Madrid, 3. ápoca, n. ${ }^{\circ} 48,7$ de octubre de 1941.

(69) ТАто (1945): 359. 
servadores españoles: «Estados Unidos adolecerá siempre de esa falta terrible, de ese salto de la pradera a la metrópoli, sin la abadía entre ambas» (70).

Para la mayor parte de observadores, la vida norteamericana no era otra que la vida neoyorquina. Una vida febril, donde las personas no andaban, corrían, bajo el ruido infernal de los automóviles y de los gritos interrumpidos y desesperados de los agentes de bolsa. La existencia del urbanita estadounidense, condenado a deglutir rápidamente un plato insípido de comida en un restaurante automático o en una cafetería, era lo más parecida a la de un autómata desprovisto de alma. Diego Hidalgo, ministro de la Guerra durante la represión de Asturias en octubre de 1934 y amigo personal de Franco desde entonces, aseguraba tras su estancia en Nueva York que ese ritmo de vida obligaba a los norteamericanos a recurrir al consumo de drogas, de pastillas, tanto para aguantar con energía su actividad fuera de casa, como para relajarse y dormir. Una imagen, en suma, distintiva de una literatura europea sobre el American Way of Life que creció en consonancia con los temores a la americanización. Frente a la seducción que suscitaba en muchos europeos el desarrollo vertiginoso del país anglosajón se resaltaba, en un tono dramatizado y caricaturesco, la pérdida de humanidad provocada por una modernidad fuera de control:

Ahora díganme ustedes si vale la pena vivir en una ciudad sometido a tanta tortura, a tanta ansiedad y desasosiego, viviendo maquinalmente y teniendo que buscar en la provocación artificial, más o menos científica, una ayuda para todos los estados, movimientos y satisfacciones naturales: para vivir, para andar, para dormir. Y así, un día y otro día, con regularidad matemática, con precisión mecánica, con exactitud cronométrica (71).

La descripción que hacía Hidalgo del modo de vida de los estadounidenses adquiría tintes apocalípticos: «Esta vida no hay quien la resista. Los nervios están siempre en tensión; los hombres mueren jóvenes» (72).

Esta retórica sobre la modernización al estilo norteamericano fue habitual en el franquismo hasta comienzos de los años cincuenta, siempre presta a utilizarse en un contexto de ostracismo internacional al que se ajustaba perfectamente. Los propios líderes del régimen, aunque más comedidos por lo general, conscientes como eran de los perjuicios que el aislamiento ocasionaba para el régimen y el conjunto del país, no dudaron en variadas ocasiones en recurrir a este tipo de discurso, cuando la conveniencia política así lo reclamaba. Por ejemplo, el mismo día en que el Congreso de los Estados Unidos rechazaba incluir a España en el Plan Marshall, el 1 de abril de 1948, Radio Nacional de España emitía un artículo de Carrero Blanco, «España ante la actual crisis mundial», en el que arremetía contra la modernidad capitalista imperante en otras

(70) Calvo Sotelo (1946): 52.

(71) Hidalgo (1947): 88.

(72) Ibíd., 309. 
latitudes (73). Como era habitual en estos años, los dirigentes franquistas camuflaban, para consumo interno, su exclusión de unas posibilidades de modernización a las que por el momento no se les permitía acceder, con una pretendida superioridad moral y espiritual.

Hay que tener en cuenta, por tanto, las dos funciones básicas desempeñadas por la reprobación a la modernización en el antiamericanismo de los primeros años del franquismo. Por un lado, este discurso se usaba para crear identidad, para definir un «nosotros» en torno a unos valores y principios singulares presentados como moralmente superiores. Por otro lado, servía para justificar un retraso y aislamiento que aparecía edulcorado y voluntario frente a la molicie y el nihilismo reinante en otras latitudes.

\section{EL CONSERVADURISMO ESPAÑOL SE AVIENE CON LA MODERNIZACIÓN AL ESTILO NORTEAMERICANO}

El inicio de la Guerra Fría marcó, en términos generales, el comienzo de un progresivo cambio en la percepción conservadora europea de los Estados Unidos. Poco a poco, los grupos situados en la derecha del espectro político fueron haciéndose cada vez más proclives hacia el país anglosajón, al contrario de lo que había ocurrido en el siglo XIX y la primera mitad del XX. El férreo compromiso de la Casa Blanca para contener el avance del comunismo en Europa fue determinante para propiciar este cambio de actitud. Las consecuencias aparejadas al ejercicio de su rol de superpotencia tras la Segunda Guerra Mundial, lo que Agustín de Foxá denominó en un exitoso artículo «el peso de la púrpura» (74), transformaron poco a poco la imagen internacional de los Estados Unidos. El país experimentó grandes cambios que, necesariamente, se tradujeron en la emisión de nuevas imágenes al exterior. Por ejemplo, una de las consecuencias más visibles de la metamorfosis causada por la Guerra Fría en la sociedad estadounidense fue en los años cincuenta la creciente influencia de los militares en la vida política, como advertía el sociólogo Wright Mills (75). Y el propio Dwight D. Eisenhower, en su famoso discurso de despedida al fin de su mandato presidencial, en enero de 1961, alertó al pueblo estadounidense sobre la peligrosa influencia de lo que él denominó por vez primera el «complejo militarindustrial» (76).

En definitiva, la nación que en el mundo contemporáneo había simbolizado los valores civiles y democráticos, adoptaba tras la Segunda Guerra Mundial

(73) Citado en De la Cosa [CARrero Blanco] (1949): 43.

(74) Agustín DE FoxÁ, «El peso de la púrpura», $A B C$, Madrid, 4 de noviembre de 1950.

(75) Wright Mills (1956): 198.

(76) Eisenhower's Farewell Address to the Nation, 17 de enero de 1961. En: http://ncadams. posc.mu.edu/ike.htm 
una fisonomía crecientemente conservadora en el interior (77) y agresiva en el exterior, a lo que contribuiría todavía más en los años sesenta el asesinato de John Fitzgerald Kennedy en noviembre de 1963 y los de Martin Luther King y Robert Kennedy en abril y junio de 1968, respectivamente (78). A partir de esta década, la implicación norteamericana en numerosos conflictos exteriores (79), muchas veces en defensa de intereses antidemocráticos, acabó por mancillar la imagen del país en buena parte de la opinión pública europea, particularmente en los sectores juveniles de la nueva izquierda, mientras que los conservadores se mostraban más comprensivos hacia los estadounidenses. En este sentido hay que tener en cuenta el esfuerzo realizado tras la Segunda Guerra Mundial por la diplomacia pública norteamericana en países como España, a la hora de presentar su sistema político y económico como compatible con el anticomunismo, el catolicismo, la defensa del orden y la familia (80).

Dentro de este contexto general, el caso español presenta algunas peculiaridades. Aunque la imagen política de los Estados Unidos mejoró en la España franquista en consonancia con el desarrollo de la Guerra Fría, sobre todo a partir del comienzo de las negociaciones bilaterales para el establecimiento de bases militares, la existencia de un régimen dictatorial cuya identidad tenía una clara impronta nacionalista y reaccionaria no hizo fácil la aparición de círculos dispuestos a defender públicamente las bondades del American Way of Life. Durante los años cincuenta, incluso después de la firma de los Pactos de Madrid en septiembre de 1953, el retroceso que experimentó el antiamericanismo, al menos públicamente, no estuvo acompañado por una nueva hegemonía de discursos favorables hacia la sociedad norteamericana (81), a pesar de los esfuerzos promovidos por Washington y varias instituciones privadas -con la Fundación Ford a la cabeza- para mejorar la imagen norteamericana en España, a través de diversos programas educativos, informativos y culturales (82). En realidad, la aparición de élites y líderes de opinión pro-americanos constituyó un proceso lento y no exento de dificultades (83).

En la evolución de la actitud conservadora española hacia los Estados Unidos, merece destacarse el papel de las élites tecnocráticas que desde finales

(77) Encarnada en fenómenos como la «caza de brujas» emprendida por el Comité de Actividades Antiamericanas o las dificultades para poner fin a la segregación racial en el sur del país.

(78) Los Kennedy habían tratado de recuperar la cara más idealista y amable de los Estados Unidos.

(79) Sin duda la participación de los Estados Unidos en la Guerra de Vietnam (1962-1975) supuso su mayor fracaso en términos de imagen.

(80) Véase, por ejemplo, NiÑo y MONTERo (2012).

(81) Aunque sí comenzaron a aparecer algunos apologistas de prestigio del país norteamericano. Entre otros, Rafael Calvo Serer, Julián Marías o Josep Pla.

(82) Véase el número monográfico «La ofensiva cultural norteamericana durante la Guerra Fría» de la revista Ayer, n. ${ }^{\circ}$ 75, 2009 (3).

(83) Véase Delgado (2012). 
de los años cincuenta ascendieron a puestos clave de la Administración franquista, introduciendo una nueva forma de hacer política más moderna que la que había predominado desde el fin de la Guerra Civil (84). La pertenencia a estas élites de opusdeístas como Alberto Ullastres, Laureano López Rodó y Mariano Navarro Rubio, pronto propagó la opinión en círculos políticos y periodísticos de que el Opus Dei dotaba de cohesión a este grupo reformista, una creencia probablemente exagerada. Lo que es indudable es que aparecía por vez primera dentro del espectro conservador español un grupo, con responsabilidades gubernamentales, que optaba abiertamente por la modernización económica del país mediante la conciliación del catolicismo con la apertura al exterior. La apuesta de esta nueva derecha por un proyecto de modernización conservadora, es decir, de una modernización concebida en términos funcionales, no en términos de valores (85), se tradujo en una mentalidad más abierta a la hora de buscar en el extranjero referentes para el desarrollo económico y social. Y, tras la Segunda Guerra Mundial, el país que marcaba la pauta de la modernización científica y económica en Occidente y, por tanto, constituía una referencia obligada para estas élites reformistas, eran los Estados Unidos. Tanto es así que, según Antonio Elorza, hubo una decidida apuesta por parte de intelectuales conservadores y élites tecnocráticas en adoptar el modelo norteamericano (86).

Aunque las políticas tecnócratas se inspiraron en un primer momento, fundamentalmente, en la ciencia económica anglosajona, optando abiertamente por la liberalización a través de un Plan de Estabilización ejecutado en coordinación con el Fondo Monetario Internacional (FMI) y la Organización Europea de Cooperación Económica (OECE), en una segunda fase, la de los planes de desarrollo, el referente principal lo constituyó la planificación indicativa francesa (87). Fue, por tanto, el pragmatismo lo que verdaderamente impulsó la acción de este grupo reformista. Pero en cualquier caso fue muy importante su apertura a nuevas ideas, conscientes de que la economía se había convertido en una ciencia imprescindible cuyo conocimiento técnico era condición necesaria para acercar a España al nivel de Europa Occidental. No es casualidad que miembros del Opus Dei como Ullastres o Calvo Serer contribuyeran a la introducción en España del pensamiento de economistas como Schumpeter o Hayek (88). Estaban dotados de una forma de entender las relaciones de la religión con lo económico que les apartaba de la rigidez de la teología política que había predominado en España desde la Guerra Civil. En 1961 el profesor de la Universidad de Illinois, Francis G. Wilson, especialista en conservadurismo, destacaba el acercamiento existente entre el Opus Dei y el protestantis-

(84) Véase FernándeZ de Miguel (2009).

(85) GonZÁlez Cuevas (2009): 135.

(86) ElORZA (2002-2003): 50.

(87) Véase Estapé (2001): 197 y De La Torre y GarCía-ZÚÑIGA (2009).

(88) Véase ORella (2014): 47. 
mo anglosajón en su manera de conceptualizar las relaciones entre la religión y la economía (89).

Los ministros tecnócratas vinculados al Opus Dei y sus aliados ideológicos vinieron a ejercer el papel de calvinistas autóctonos, desenterrando el «sentido reverencial del dinero» que años atrás había defendido Ramiro de Maeztu como clave explicativa del poderío anglosajón en el mundo moderno. Fueron ellos los responsables de superar las reticencias del catolicismo en sus siempre difíciles relaciones con la modernización capitalista, lo que les valió duras críticas por parte de otros sectores del régimen, como los falangistas (90) o católicos de la línea tradicionalista (91).

La nueva política económica puesta en marcha desde 1957 contribuyó a acelerar de forma vertiginosa un proceso de modernización económica que rápidamente transformó los valores sociales dominantes en España hacia una línea hedonista de consumo, más acorde con el resto del mundo occidental (92). En consonancia con este proceso, intelectuales destacados del conservadurismo español, como Rafael Calvo Serer (93) o Gonzalo Fernández de la Mora, dieron cobertura ideológica a los logros modernizadores del régimen. En el caso del primero, mediante la conciliación del desarrollo español con ciertos aspectos del liberalismo norteamericano (94), y en el caso del segundo, mediante la importación de la teoría de la modernización y el fin de las ideologías (95). Como señalaba Fernández de la Mora: «El desarrollo económico dignifica al hombre $\mathrm{y}$, entre innumerables efectos secundarios, concentra la atención utilitaria de las masas en el trabajo productivo, despegándolas de la batalla política» (96). También participaron en este proceso ideológico de legitimación revistas como Atlántida, dirigida por Florentino Pérez-Embid, en la que Fernández de la Mora desempeñó un papel muy activo a la hora de identificar modernismo neoconservador con tecnocracia (97).

(89) WILSON (1961): 159.

(90) Conocido es el lema «Por el dinero hacia dios» creado por el entonces director del diario Arriba, Rodrigo Royo, para ridiculizar a los miembros del Opus.

(91) Entre los que destacó la revista Punta Europa. Su director, Vicente Marrero, consideraba que la tecnocracia divorciaba la política de la ética, ya que su meta era «la perfección de la misma técnica y no la perfección del hombre como tal».

(92) Véase Townson (2009) y Tortella (1994): 255-429.

(93) Aunque Calvo Serer, a finales de los años sesenta, acabaría ingresando en las filas de la oposición al régimen franquista.

(94) A finales de los años cincuenta, Calvo Serer quedó deslumbrado por la sociedad norteamericana tras una estancia en el país. A continuación escribió obras muy laudatorias hacia el modelo estadounidense, como La fuerza creadora de la libertad (1959) y Las nuevas democracias (1964), ambas editadas por Rialp.

(95) En obras como El crepúsculo de las ideologías (1965) o la más tardía El Estado de obras (1976), editadas por Rialp y Doncel respectivamente.

(96) FERNÁNDEZ DE LA MORA (2013) [1965]: 187.

(97) GónZalez Cuevas (2012): 127-136. 
A mediados de los años sesenta, las condiciones sociales del país habían cambiado de tal manera, que las soflamas reaccionarias y quijotescas del primer franquismo parecían corresponder a una época muy lejana:

Cuando uno se toma una cerveza en la terraza de un café de Madrid o cuando se baña en una playa mediterránea, le cuesta imaginar que este fue un país de curas fanáticos que mandaban matar para defender la Santa Madre Iglesia, de santones tétricos y de beatos de misa y olla (...) Hace no más de veinte años, España era aún un país romántico del siglo XIX (98).

La rápida transformación económica y social experimentada por España a lo largo de los sesenta vino acompañada por una creciente presencia norteamericana en la cultura popular y en las nuevas formas de consumo. Esta vez sí, el Imperio del Mercado avanzaba sin cortapisas en España, propagando la cultura del consumo estadounidense. Al final de la década, la americanización de aspectos notables de la sociedad española constituía una realidad (99). El impacto de la cultura del consumo norteamericana, especialmente entre los jóvenes, a través de la música popular como el rock and roll, las películas de Hollywood, la vestimenta con prendas como los pantalones vaqueros, y los cómics, con el género de los superhéroes impulsado por Marvel, fue un fenómeno generalizado en la Europa de finales de los cincuenta y los sesenta, al que España se incorporó algo más tardíamente: «La América real o imaginaria se estaba convirtiendo en el escenario natural de todos los géneros de entretenimiento» (100).

Este proceso de americanización, que adquirió un alcance e intensidad nunca antes equiparable en la sociedad española, no provocó, sin embargo, las mismas reacciones de antaño en los medios conservadores. Cierto es que, en la cultura conservadora, siguieron vigentes algunos recelos hacia la sociedad norteamericana, a la que se seguía vinculando con viejos tópicos, aunque ya más tolerados, como el materialismo y la ignorancia cultural, y se añadían nuevas lacras, como la delincuencia, las drogas o los divorcios. Las observaciones de Miguel Delibes tras visitar el país a mediados de los años sesenta son bastante paradigmáticas de esta visión (101). Pero solo en algunos grupos minoritarios de extrema derecha, con escasa capacidad de movilización, el rechazo de carácter antimoderno hacia los Estados Unidos siguió teniendo fuerza (102). Para explicar este fenómeno, conviene tener en cuenta la progresiva relegación de los círculos católicos que quedaron al margen de la evolución en un sentido más

(98) Triguero (1965): 5. Juan Triguero era el pseudónimo de José María Moreno Galván, intelectual y crítico de arte.

(99) CORTADA (1978): 237.

(100) JUDT (2008): 517.

(101) DeLiBEs (1966). Miguel Delibes visitó el país invitado en el marco del Foreign Leader Program, uno de los programas impulsados por los Estados Unidos para mejorar su imagen respecto a líderes de distintos ámbitos de otras naciones.

(102) Fue el caso de Blas Piñar y Fuerza Nueva, el diario El Alcázar o revistas integristas como ¿Qué pasa? 
tolerante, conforme al Concilio Vaticano II (1962-1965), de la mayor parte de los católicos españoles. Estos sectores más conservadores identificaron el avance de la modernización al estilo norteamericano como una operación del capitalismo estadounidense y, al igual que décadas atrás cuando alertaban sobre el «peligro protestante», acusaron a grupos cristianos procedentes de los Estados Unidos (adventistas, mormones, testigos de Jehová, etc.), de formar parte de un proyecto político y económico de dominación llevado a cabo de forma subrepticia:

Los «testigos de Jehová» son, sin duda, una organización creada para inculcar en el pueblo el espíritu de mansedumbre (entiéndase bien, solo el espíritu de mansedumbre), con el fin de allanar el camino opresor del capitalismo (la táctica de siempre) y, por otra parte, restar miembros a la Iglesia Católica (...) Nosotros solo quisiéramos que nos explicase [el pastor de los testigos de Jehová] qué piensan ellos sobre la opresión que el capitalismo, usando todas sus ya viejas tácticas, ejerce sobre tantos pueblos del mundo y qué doctrinas defienden en el campo de lo social y económico, y qué hacen ellos para combatir esta opresión, o, al menos, qué obras sociales tienen en marcha, ya que están tan «hermanados». Pero estamos seguros de que no nos lo explicará quien está a sueldo de ese capitalismo (103).

Este lenguaje anticapitalista y antiimperialista emulaba al que se transmitía en los ambientes de izquierda, desde donde se lideraba ahora la oposición a los Estados Unidos (104). Por el contrario, una buena parte de los conservadores españoles comenzaba a interesarse por la «América de una planta», por emplear la metáfora creada por los escritores soviéticos Ilf y Petrov cuando viajaron por el país a mediados de los años treinta (105). Es decir, una Norteamérica de casas bajas, de pueblos y ciudades de tamaño medio, familiar, religiosa y conservadora. Una Norteamérica, en suma, muy lejos de la encarnada por Nueva York y Chicago de la que tanto habían abominado en el pasado.

\section{CONCLUSIONES}

En España, como en el resto de Europa, predominó una visión de la modernización al estilo norteamericano muy ligada a su carácter económico, productivo y de consumo, con sus manifestaciones sociales más visibles en la aparición de nuevas formas de ocio y entretenimiento para masas que ponían en cuestión la hegemonía de usos y costumbres más tradicionales y clasistas. Únicamente sectores reducidos pero importantes cualitativamente del ámbito educativo y cultural se fijaron en otros aspectos de la modernización proceden-

(103) «Los testigos de Jehová», ¿Qué pasa?, Madrid, n. ${ }^{\circ}$ 73, 20 de mayo de 1965.

(104) Véase SEREGNI (2010).

(105) Ilf y Petrov (2009) [1937]. 
te de los Estados Unidos, esto es, en sus grandes logros en términos de progreso científico y tecnológico.

Entre los creadores de opinión españoles del primer tercio del siglo Xx, sobre todo los de carácter más conservador, prevalecía una mirada análoga a la que se tenía por parte de un sector significativo de la intelectualidad hispanoamericana y europea, principalmente francesa. Desde principios del siglo, intelectuales de diversos países latinoamericanos habían articulado una corriente muy contraria a la modernización estadounidense, a la que oponían una alternativa hispana, de carácter católico, espiritual, despreciativa del materialismo y utilitarismo anglosajones. Es una visión que heredó los conflictos decimonónicos que, desde un punto de vista racial, oponían el ascenso fulgurante de la raza anglosajona al estancamiento de la hispana. Frente a una modernidad aparentemente exitosa que ofrecía eficiencia económica, desarrollo tecnológico y consumismo, al precio de que los individuos quedaran anulados por las fuerzas ciegas del mercado y el maquinismo, numerosas voces desde Hispanoamérica y Europa presentaron como salvaguarda un estilo de vida asentado en un pasado precapitalista, donde reinaba el desinterés material, la espiritualidad, la tranquilidad, el refinamiento cultural... Un modelo idealizado, inexistente en la práctica, pero que servía como escape a la angustia producida por el avance de una sociedad de masas que, a ojos de los críticos con el American Way of Life, se exportaba desde las grandes ciudades norteamericanas al resto del mundo.

Mientras en los países más industrializados y avanzados tecnológicamente de Europa, como Alemania y el Reino Unido, los debates sobre los Estados Unidos en el periodo de entreguerras no se ciñeron únicamente a los aspectos sociales y culturales más peculiares del Américan Way of Life, sino que abarcaron también las claves de su eficiencia económica, desarrollo tecnológico y métodos de organización laboral y empresarial, en España y, en general, los países latinos, predominó con más fuerza la crítica moral y social. En realidad, estos grupos críticos con la modernización procedente de los Estados Unidos tendían a culpar a la americanización «por la pérdida de una Europa que no había existido nunca, un continente seguro en su identidad, su autoridad y sus valores, e inmune a los cantos de sirenas de la modernidad y la sociedad de masas» (106).

Durante el primer franquismo, coincidiendo con el protagonismo político y social de grupos muy conservadores, contrarios ya no solo a las innovaciones procedentes de los Estados Unidos sino a la modernidad en general, se produjo un intento de blindar la sociedad española a la influencia exterior. Su talante reaccionario, muy visible en el ámbito educativo y moral, era refractario a cualquier atisbo de importación procedente de la sociedad norteamericana, que se erigía en los años cuarenta como la más destacada representante de la vida moderna.

En este período todavía tenía vigencia, al menos en términos retóricos, la idea de que existía una vía alternativa de desarrollo, hispana, antitética a la mo-

(106) JUDT (2008): 518. 
dernización al estilo norteamericano. El aislamiento internacional contribuyó a que estas actitudes encontraran frecuentemente el amparo oficial, dada su funcionalidad a la hora de presentar en positivo la imposibilidad de acceder a la amistad norteamericana y, en consecuencia, al apoyo a la modernización de que disfrutaban otros países europeos. Esta exclusión aparecía como una decisión voluntaria de los españoles de mantenerse al margen del corrompido mundo moderno, sin contaminarse de sus perniciosos efectos. La excepcionalidad española se glorificaba una vez más.

En poco tiempo este escenario experimentó grandes cambios. La agudización de la Guerra Fría ofreció a las autoridades franquistas oportunidades de acercamiento a los Estados Unidos que no fueron desaprovechadas. Al mismo tiempo, aunque en los principales círculos políticos, religiosos e intelectuales siguiera predominando una valoración negativa de la modernidad, cada vez se hacía más evidente la necesidad de integrarse en ella, si se quería garantizar la permanencia del régimen. Las élites tecnocráticas que, en la segunda mitad de los años cincuenta, ascendieron a puestos claves de la dirección del Estado, compartían esa idea. Su objetivo de situar a España en la senda de la modernización económica hizo que, por vez primera en el conservadurismo español, un grupo influyente del mismo, con responsabilidades gubernamentales, adoptara una actitud favorable al modelo estadounidense, siguiendo su ejemplo en áreas estratégicas de desarrollo.

Las políticas tecnocráticas contribuyeron a las importantes transformaciones que experimentó la sociedad española durante los años sesenta, y se tradujeron en una mayor americanización de su cultura popular y de consumo, al igual que ocurría en el resto de Europa Occidental. Pensadores como Gonzalo Fernández de la Mora o Rafael Calvo Serer, así como publicaciones como Atlántida legitimaron en el terreno de las ideas los logros modernizadores del régimen, importando a España la teoría de la modernización, el fin de las ideologías, la subsunción del ciudadano en consumidor, justificando la aparición de una cultura política más acorde a la existente en los Estados Unidos y Europa Occidental, donde las expectativas de mejora social y de bienestar económico ocuparon el lugar del radicalismo ideológico.

\section{BIBLIOGRAFÍA}

(1939): Símbolos de España: Librito escolar de lectura, Madrid, Editorial Magisterio Español.

Aguado, Ana y Ramos, M. ${ }^{a}$ Dolores (2002): La modernización de España (19171939). Cultura y vida cotidiana, Madrid, Editorial Síntesis.

AlmazÁn, DAVID y RodAo, FloRentino (2006): «Japonizar España: La imagen española de la modernización del Japón Meiji», en Modernizar España 1898-1914. 
Congreso Internacional: Comunicaciones, formato CD, Madrid, Universidad Complutense.

Álvarez Bolado, Alfonso (1976): El experimento del nacionalcatolicismo (19391975), Madrid, Edicusa.

Álvarez Junco, José (2001): Mater Dolorosa. La idea de España en el siglo XIX, Madrid, Taurus.

Araquistain, Luis (1924): El peligro yanqui, Valencia, Editorial Sempere, 2. a ed.

BAKER, EDWARD (2009): Madrid cosmopolita . La Gran Vía, 1910-1936, Madrid, Marcial Pons.

BAKer, Edward y CASTRo, Demetrio (2008): «Presentación. Espectáculos en la España contemporánea: de lo artesanal a la cultura de masas», en Ayer, 72, pp. 13-26.

BlaCk, CyRIL E. (1966): The Dynamics of Modernization; a study in comparative history, New York, Harper \& Row.

Blanco-Fombona, Rufino (1902): La americanización del mundo, Amsterdam, Imprimerie Electrique.

Botti, Alfonso (2008): Cielo y dinero. El nacionalcatolicismo en España (18811975), Madrid, Alianza Editorial, 2. ${ }^{\mathrm{a}}$ ed.

Calvo Sotelo, Joaquín (1946): Nueva York en retales, Madrid, Editorial Dossat.

CAPEllán de Miguel, Gonzalo (2011): «La república norteamericana como modelo político para el krausismo español», en Bulletin d'Histoire Contemporaine de l'Espagne, n. ${ }^{\circ} 46$, pp. 43-70.

Carreras, Albert y TAFunell, XAVIER (Coords.) (2006): Estadísticas históricas de España. Siglos XIX y XX, Bilbao, Fundación BBVA.

Cereceda, Feliciano (1940): Historia del Imperio español y de la Hispanidad, Madrid, Editorial Razón y Fe.

Chías Navarro, Pilar (1986): La Ciudad Universitaria de Madrid, Madrid, Editorial Complutense.

Cortada, James W. (1978): Two Nations Over Time. Spain and the United States, 1776-1977, Connecticut, Greenwood Press.

DARío, RubÉN (1898): «El triunfo de Calibán», en El Tiempo, 20 de mayo de 1898.

De AzCÁrate, Gumersindo (1892): Los Estados Unidos, Madrid, Establecimiento Tipográfico «Sucesores de Rivadeneyra».

De Grazia, Victoria (2005): Irresistible Empire. America's Advance through Twentieth-Century Europe, Cambridge (Massachusetts), The Belknap Press of Harvard University Press.

De la Cosa, JuAn [CARrero Blanco] (1949): La gran baza soviética, Valencia, Semana Gráfica.

De la Torre, Joseba y García-ZÚÑIGA, MARIo (2009): Entre el mercado y el Estado: Los planes de desarrollo durante el franquismo, Pamplona, Universidad Pública de Navarra.

De Labra, Rafael María (1877): El Derecho Internacional y los Estados Unidos de América, Madrid, Administración de El Abolicionista.

Del Arco y Garay, Ricardo (1942): Grandeza y destino de España, Madrid, Editorial Escelicer. 
Delgado, Lorenzo (2012): «Objetivo: atraer a las élites. Los líderes de la vida pública y la política exterior norteamericana en España», en Guerra Fría y propaganda. Estados Unidos y su cruzada cultural en Europa y América Latina, Madrid, Biblioteca Nueva, pp. 235-277.

(2009): «La Comisión Fulbright y la cooperación cultural con Estados Unidos», en La modernización científica de España, Madrid, Instituto de España, pp.139-174.

DeliBes, Miguel (1966): USA y yo, Barcelona, Ediciones Destino.

Domingo, Marcelino (1923): La isla encadenada: viajando por América, Madrid, Rivadeneyra.

Duhamel, Georges (1930): Scènes de la vie future, París, Mercure de France.

ELORZA, ANTONIO (2002-2003): «Les sources de l'anti-américanisme espagnol», en Les cahiers d'histoire sociale, Hiver 2002-2003 (n. ${ }^{\circ} 21$ ), pp. 43-56.

Estapé, FABIÁn (2001): Sin acuse de recibo, Barcelona, Plaza y Janés.

FERNÁNDEZ DE LA MoRA, GonZAlo (2013) [1965]: El crepúsculo de las ideologías, Hildesheim, Georg Olms Verlag.

FERnÁNDEZ DE Miguel, DANIEL (2011): El enemigo yanqui. Las raíces conservadoras del antiamericanismo español, Madrid, Genueve Ediciones.

- (2009): «La erosión del antiamericanismo conservador durante el franquismo», en Ayer, 75, pp. 193-221.

FERRIS, KATE (2010): «Technology, Novelty, and Modernity: Spanish perceptions of the United States in the Late Nineteenth Century», en Hispanic Research Journal, 11/1, pp. 37-47.

García-Montón, María IsABel (2002): Viaje a la modernidad: la visión de Estados Unidos en la España finisecular, Madrid, Verbum.

GINER DE LOS Ríos, FRANCISCO (1928) [1898-1901]: «Informes del Comisario de Educación de los Estados Unidos», en Obras Completas, Madrid, La Lectura.

González Cuevas, Pedro Carlos (2012): «Punta Europa y Atlántida: Dos respuestas a la crisis de la teología política», en Historia y Política, 28, pp.109-138.

- (2009): Conservadurismo heterodoxo. Tres vías ante las derechas españolas: Maurice Barrès, José Ortega y Gasset y Gonzalo Fernández de la Mora, Madrid, Biblioteca Nueva.

González Menéndez-Reigada, Albino (1939a): Catecismo patriótico español, Salamanca, Establecimiento Tipográfico de Calatrava, 3. ${ }^{a}$ ed.

- (1939b): Los enemigos de España, La Laguna-Tenerife, Imprenta Católica Pacheco.

GuldDal, JesPer (2011): Anti-Americanism in European Literature, Palgrave Macmil-lan, New York.

Hidalgo, Diego (1947): Nueva York. Impresiones de un español del siglo XIX que no sabe inglés, Madrid, M. Aguilar.

Higham, John (1955): Strangers in the Land: Patterns of American Nativism, 18601925, New Jersey, Rutgers University Press. 
IGLESIAS, IVÁN (2010): «(Re)Construyendo la identidad musical española: el jazz y el discurso cultural del franquismo durante la Segunda Guerra Mundial», en Historia Actual Online, 23 (Otoño), pp.119-135.

Ilf y Petrov (2009) [1937]: La América de una planta, Barcelona, Acantilado.

InIESTA CORREDOR, Alfonso (1941): El orden nuevo en la educación de las juventudes, Madrid, Editorial Magisterio Español.

Judt, Tony (2008): Postguerra. Una historia de Europa desde 1945, Madrid, Taurus.

Juliá, SANTOS (2011): «Europeizar España: Ortega y Azaña encuentran a Costa», en Joaquín Costa. El fabricante de ideas, Zaragoza, Gobierno de Aragón, Dirección General de Cultura, pp.109-118.

KlautKe, EgBert (2011): «Anti-Americanism in twentieth-century Europe», en The Historical Journal, 54, pp. 1125-1139.

León Aguinaga, Pablo (2010): Sospechosos habituales. El cine norteamericano, Estados Unidos y la España franquista, 1939-1960, Madrid, CSIC.

MAyer, Arno J. (1981): The Persistence of the Old Regime: Europe to the Great War, New York, Pantheon Books.

NiÑo, Antonio (2012): La americanización de España, Madrid, Los Libros de la Catarata.

(2009): «Miradas españolas al modelo americano en el periodo de entreguerras», en Razones de historiador. Magisterio y presencia de Juan José Carreras, Zaragoza, Instituto Fernando el Católico, pp. 405-420.

(2001) «La europeización a través de la política científica y cultural en el primer tercio del siglo XX», en Arbor, CLXX/669, pp. 95-126.

- y Montero, José ANTONIO (eds.) (2012): Guerra Fría y propaganda. Estados Unidos y su cruzada cultural en Europa y América Latina, Madrid, Biblioteca Nueva.

Nolan, Mary (1994): Visions of Modernity: American Business and the Modernization of Germany, New York, Oxford University Press.

Orella, José LuIs (2014): La España del desarrollo: El almirante Carrero Blanco y sus hombres, Madrid, Galland Books.

PElls, Richard (1997): Not Like Us. How Europeans have love, hated, and transformed American culture since World War II, New York, Basic Books.

Polanyi, Karl (1944): The Great Transformation, New York, Farrar \& Rinehart.

Rodó, José EnRIQue (1947) [1900]: Ariel, Buenos Aires, Editora y Distribuidora del Plata.

Rodríguez, P. TEOdoro (1940): Nueva campaña de mentiras e insidias contra Espa$\tilde{n} a$, Madrid, Impr. J. Bravo.

Rodríguez Jiménez, Francisco y Fernández de Miguel, Daniel (2011): «La larga durabilidad de los estereotipos. El peso de los prejuicios en la visión española de Estados Unidos», en Cuadernos de ALDEEU, 23, pp.33-57.

SÁNCHEZ Ron, José MANUEL (2009): «La internacionalización de la ciencia española: la Junta para la Ampliación de Estudios y la fundación Rockefeller», en La modernización científica de España..., op. cit., pp. 107-138. 
SEREGNI, AlesSANDRO (2010): «Antiamericanismo y democracia», en Claves internacionales en la Transición española, Madrid, Libros de la Catarata, pp.128-147.

Serrano de Haro, Agustín (1943): Yo soy español, Madrid, Editorial Escuela Española.

Sopeña Monsalve, Andrés (1994): El florido pensil, Barcelona, Crítica.

StEAD, W.T. (1902): The Americanization of the World, New York-London, Horace Markley.

TAto Cumming, Gaspar (1945): Nueva York. Un español entre rascacielos, Madrid, Editorial Febo.

Tortella, GABRIEl (1994): El desarrollo de la España contemporánea. Historia económica de los siglos XIX y XX, Madrid, Alianza.

Townson, Nigel (2009): España en cambio. El segundo franquismo, 1959-1975, Madrid, Siglo XXI.

Triguero, JuAn (1965): «La generación de Fraga y su destino», en Cuadernos de Ruedo Ibérico, 1, pp. 5-16.

Ugarte, Manuel (1920): El porvenir de la América Española, Valencia, Prometeo.

VARGas VILA, JosÉ MARía (1930) [1903]: Ante los bárbaros: el yanki, he ahí el enemigo, Barcelona, Ramón Sopena.

Wilson, Francis G. (1961): «The New Conservatives in Spain», en Modern Age (Spring), pp.149-160.

Wright Mills, Charles (1956): The Power Elite, New York, Oxford University Press. 
